\title{
DISCOURSE ANALYSIS OF DECENTRALIZATION POLICY MAKING PROCESS OF PROTECTED FOREST MANAGEMENT
}

\author{
Sulistya Ekawati ${ }^{1}$, Hariadi Kartodihardjo ${ }^{2}$, Dodik Ridho Nurrochmat ${ }^{2}$, Hardjanto ${ }^{2}$ \\ and Hariyatno Dwiprabowo
}

Received : 4 October 2012, Accepted : 4 December 2013

\begin{abstract}
Decentralization of protected forest management from central to district government has not yet been implemented effectively. This effectiveness depends on many factors that include policy contents and political process or discourse in the policy making process. This study aims to: 1) analyze the discourse in policy making process of decentralization in the management of protected forests, 2) analyze the actors/networks and their interests and 3) find out policy space for future policy reform. Both quantitative and qualitative approaches were used in the study. The results show that there are three discourses in the policy-making process of decentralized management of protected forests, namely: i) democratic discourse (with story line of externality and accountability, supported by an association forum of Indonesian district government and decentralization experts); ii) economic discourse (with story line of efficiency, supported by businessmen, Association of Indonesian Provincial Government and World Bank); and iii) democratic and economic discourses. The House of Representatives (DPR) and Ministry of Home Affairs have authorities and capacities to integrate two discourses. Redefining of externality and interdependency can be used as narratives of new policies to improve the policy of decentralized protected forest management.
\end{abstract}

Keywords: Policy process, discourse, decentralization, protected forests

\section{INTRODUCTION}

Protected forests are defined as forest areas with the main functions to protect life support systems, such as to manage the water system, to prevent the occurrence of floods, erosion, sea water intrusion and to maintain soil fertility. Protection forests are common pool resources. Protection forests provide both positive and negative externalities, which are causing inter dependence between the up stream and down stream districts (Kartodihardjo, 2006).

Decentralizationis defined as any action where the central government formally concedes its authority to the actors or institutions at lower levels in a political-administrative and territorial hierarchy (Ribbot and Larson, 2005; Barr et al., 2006). The division of authority between government levels is a very important factor in the

\footnotetext{
Researchers at the Center for Climate Change and Policy

${ }^{2}$ Lecturerat the Forestry Faculty, Bogor Agricultural University

${ }^{*}$ Corresponding Author: ekawati69@yahoo.com
}

decentralization. At the beginning of its implementation, the division of authorities between levels of government in decentralization was regulated according to Government Regulation No. 25/2000, which adopted an opened arrangement system. The regulation did not clarify in detail the division of authorities, causing ambiguities of authority.

The government revised the regulation, by issuing Government Regulation No.38/2007, concerning the division of authorities between the Central, Provincial and District Governments. Government Regulation No.38/2007 followed the "principle of ultravires", in that the distribution of authority to local government is set out in detail by issuing new regulation (Hoessein andPrasodjo, 2009).

The division of governmental affairs in the forestry sectoris described in Annex AA of Government Regulation No.38/2007. According to that regulation, the management of protected forest is decentralized to district government. The management of protected forests covers the 
following activities: forest inventory, forest rehabilitation, forest protection, permit to utilize the forest area, collection of non-timber forest products that are not protected nor included in the CITES' appendix, nor in the use of environmental services at district-level.

Political framework of decentralization of policy formulation in natural resource management and environment (including management of protected forest), is still based on administrative approach and not yet based on ecosystem approach ${ }^{1}$. The existing mistake of local governance lies in the absence of a comprehensive management based on managing natural resources. The management of natural resources use political perspective, so that political interests strongly influence the decision making process. Consequently, in many regions natural resources are exploited extensively and managed in an unsustainable way.

Deforestation in protected forest continues even a decade after the implementation of the decentralization policy in forestry. Policy failure could be caused by two issues : the content of the policy it self and its implementation (Sutton, 1999). The actors who are involved in the policy making process have differences in the conceptual framework. Policy-making process cannot be separated from the "narrative/ discourse". The debates are mostly the underlying factors that influenced the formulation of Government Regulation No. 38/2007. These cover the perspectives developed at the time, the ones that played the important roles in the policy-making process, the context, and the influence targeted by the policy change. This study aims to analyze narratives and discourses developed in the policy making process of decentralization of forest management, to analyze actors/networks involved and their interests, to find policy space to improve decentralization policies for better management of protected forest in the future.

\section{METHODOLOGY}

\section{A. Analysis Framework}

The analytical framework used in this study refers to the policy making process as proposed by the Institute of Development Studies (IDS, 2006) and Sutton (1999), which develops and elaborates a simple framework of three inter-related themes (Figure1).

a. Conceptual framework

Policy narrative is like a story. It has a beginning, middle and end sections, outlining a specific event which has gained status of conventional wisdom. A narrative is born through policy maker's network which develops its own paradigm, so it becomes very powerful (Sutton, 1999). Discourse is a set of ideas, concepts and categories to create new meaning. It is supported by scientific theory, rooted in and use of certain methodological approaches. Discourses define problems, and classify people who have an important influence in policy making process. Policy narratives and discourses explain how the story came up and what needs to be done to avoid failure or to achieve a successful ending, what is wrong and how the problems are solved. Policy makers often make decisions on the stories

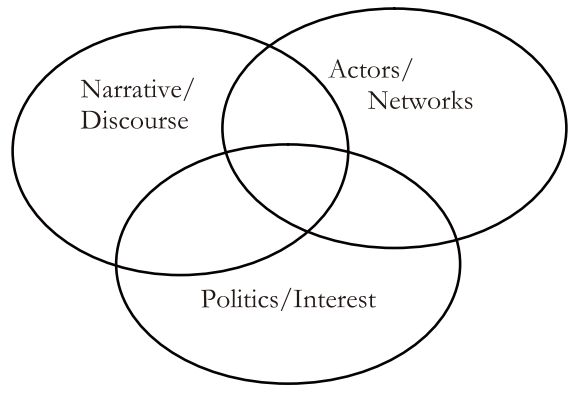

Figure 1.Analysis of policy-making process (IDS, 2006; Sutton, 1999)

\footnotetext{
${ }^{1}$ Record of Focus Groups' Discussion on Sectoral Forest Resources. Perspective of Forest Resource Managementas a Regional Asset in the Revised Law 32/2004 on Regional Government.
} 
described in the narrative development.

Policy narrative is different from discourse, which refers to a value and a broader way of thinking. A narrative can be part of a discourse if it describes a specific "story" line with the broader set of values and priorities of a discourse.

\section{b. Actors/network}

Networks, coalitions and alliance of actors are important in spreading and maintaining narratives. Networks are formed by the same vision, similar beliefs and code of ethics. They do public persuation through journals, conferences, education or informal ways. Negotiation and bargaining processes between groups with competing interests play an important role in policy making.

\section{c. Interests and Politics}

The policy process is influenced by several groups with different interests and each of them uses power and authority during the policymaking. Interests of actors in the policy making process come from government agencies, donor organizations and independent experts.

\section{B. Data Collection'Techniques}

Data were collected through purposive sampling, from February 2003 to July 2007. These data were collected in two steps, namely:

a. Establishing coding units to select and categorize several texts related to division of authority for policy-making process among levels of government. The coding units consist of newspapers, research reports, articles, books and journals. The total examined documents were 56 , consisting of 33 popular papers (16 papers from printed media and 17 papers from website) and 23 scientific papers (10 scientific articles, 5 scholarly journal papers and 8 books) (Appendix1). All of those documents were tabulated in a form of categorization in order to provide text description related to division of authority for policy-making process.

b. In-depth interviews with government officers from national to sub-national levels involved in the division of authority for policy-making process between government levels. In-depth interviews were conducted to prevent misunderstanding in interpreting concepts used in the study and to complete the missing data.

\section{Data Analysis}

Discourse was analyzed quantitatively and qualitatively. Quantitative analysis was conducted by counting the frequency statement of certain issue in the text. Qualitative analysis was carried out by using social change model, which was developed by Fairclough (2006). In this model, discourse is seen as a frame, and is conducted to investigate the meanings of words, texts and to identify the relationship between discourse and implementation. The model analyzes how the policy narratives of authority division are formed; how conflicts between policy narratives arise; what kind of problem solutions fit to those policy narratives; who play an important role in decision making; and what are their interests.

\section{RESULT AND DISCUSSION}

\section{A. Policy Narrative and Discourse}

Draft of Government Regulation No. 38/ 2007 used three criteria as the basics of dividing authority i.e. externality, accountability, and efficiency. In fact, there are policy narratives for division of authority among levels of government namely: externality, accountability, efficiency, subsidiary, catch mentarea and connectivity (Table1).

Results of the text analysis show that most of the policy narratives $(73.15 \%)$ were found in scientific text, while others $(26.87 \%)$ were found in popular text. This condition explains that a policy narrative is usually constructed through certain theories inherent in a particular group. Knowledge based approaches in scientific literature are very important and powerful in influencing decision-makers' perceptions.

There are three dominant policy narratives in the division of authority for the policy-making process, namely: externality $(23.89 \%)$, accoun- 
Table 1. Policy narrative that develops in the policy-making process for division of authority among levels of government

\begin{tabular}{|c|c|c|c|c|c|c|c|}
\hline \multirow[b]{2}{*}{ No } & \multirow[b]{2}{*}{ Policy narrative } & \multicolumn{2}{|c|}{ Popular text } & \multicolumn{2}{|l|}{ Scientific text } & \multicolumn{2}{|c|}{ Total } \\
\hline & & $\begin{array}{l}\text { Frequency } \\
\text { (times) }\end{array}$ & $\begin{array}{c}\text { Percent } \\
(\%)\end{array}$ & $\begin{array}{c}\text { Frequency } \\
\text { (times) }\end{array}$ & $\begin{array}{c}\text { Percent } \\
(\%)\end{array}$ & $\begin{array}{l}\text { Frequency } \\
\text { (times) }\end{array}$ & $\begin{array}{c}\text { Percent } \\
(\%)\end{array}$ \\
\hline 1. & Externality & 5 & 7.46 & 11 & 16.42 & 16 & 23.89 \\
\hline 2. & Accountability & 6 & 8.96 & 13 & 19.40 & 19 & 28.36 \\
\hline 3. & Efficiency & 6 & 8.96 & 15 & 22.40 & 21 & 31.34 \\
\hline 4. & Subsidiary & 0 & 0 & 3 & 4.48 & 3 & 4.48 \\
\hline 5. & Catchment area & 0 & 0 & 4 & 5.97 & 4 & 5.97 \\
\hline 6. & $\begin{array}{l}\text { Connectivity/interdependency/ } \\
\text { interconnection }\end{array}$ & 1 & 1.49 & 3 & 4.48 & 4 & 5.97 \\
\hline & Total & 18 & 26.87 & 49 & 73.15 & 67 & 100 \\
\hline
\end{tabular}

tability $(28.36 \%)$ and efficiency $(31.34 \%)$. This is understandable because the Ministry of Home Affairs as the dominant actor try to use its influence indrafting the policy using the three policy narratives. However, there are several other criteria proposed by experts which receive small portions, namely subsidiary, catchment area, and connectivity with $4.48 \%, 5.97 \%$ and $5.97 \%$ respectively.

The policy narrative of externality refers to the division of authority approach by considering impact/consequences that may appear when government affairs enter into force. If government affairs have caused local impact, the district level will have the authority. On the contrary, if goverment affairs have caused regional impacts, provincial government will take care of the affair. The central government has the authority for all affairs that have national impacts.

The level of authority is determined by the extent, magnitude and range of impact sarising from the implementation of government affairs. The broader externality is generated, the higher authority is required to handle such affairs. For example, according to Satija (2003), Ratnawati et al. (2003), and Zuhro et al. (2006), rivers or forests that have regional externality should be the responsibility of provincial government.

Criteria of accountably based on the proximity of the impact caused by the delivery of the affair. Criteria of the efficiency is determined based on comparison of the highest usefulness that can be obtained. Measure of the effectiveness and efficiency is determined by the amount of benefits perceived by community and the size of risks that must be faced (Suwandi, 2002; Satija, 2003).

Criteria of catchment area require an accurate determination of boundary because it relates to area coverage in order to provide optimal public services. The criteria of catchment area are combined with efficiency criteria. Some experts mentioned that the economies of scale can be achieved through an optimum service coverage (catchment area). Criteria of subsidiary mean that implementation of the duties and authority is carried out by the lowest levels of government. Connectivity criteria means that implementation of authority is carried out by respecting the relationship between levels of government (Suwandi, 2002; Satija, 2003).

Narrative need to be criticized because it is believed to be as a blue print maker, in which all solutions of problems that have been formulated at a particular time and with a scope that does not often fit with the current situation (Sutton, 1999). Three dominant policy narratives are difficult to implement. Narrative policy of catchment areas and connectivity/interdependency/interconnection are also used as policy narrative, even though they are not the main narrative, but linked to support the dominant narrative. Narrative of catchment area is associated with the efficiency narrative, while the use of the three dominant narratives (externality, accountability and efficiency) is carried out by stressing harmonization among levels of government.

A narrative can be part of the discourse when describing a particular story that is consistent to broader values and priorities (Sutton, 1999). The mission of democracy discourse is to develop democracy in implementing governance. There are several values that reflect democracy namely participation, equality, accountability, externalities. Economic discourse is associated with implementation of public services effectively, efficiently and economically (Suwandi, 2002; Zuhro, 2006). The value that reflects economic 
discourse is efficiency. The coalition of democratic and economic discourse is constructed from policy narratives of externality, accountability and efficiency (Suwandi, 2002; YAPPIKA, 2006). From the analysis, there are three discourses raised in the policy-making process for the division of authority among levels of government in Indonesia, namely: 1) democratic discourse with externality and accountability policy narratives, 2) economic discourse with efficiency policy narrative and 3) democratic and economic discourses with externality, accountability and efficiency policy narratives.

\section{B. Actor/Network}

Parson (2008), stated that policy process as a whole can be understood in the context of networks and policy communities. There are several actors involved in policy-making process (see Table 2).

Table 2 shows that there are four main actors that are involved in the policy-making process. These are: Central Government (34.31\%), Association of Local Government (18.63\%), Parliament (17.65\%) and universities/ researchers/experts (16.67\%). At Central Government, institution which was involved most is the Ministry of Home Affairs. Association of Indonesian District Government (APKASI), Association of Indonesian Municipalities Government (APEKSI), Association of Indonesian District Parliament (ADKASI) and Association of Indonesian Municipal Parliament (ADEKSI) agreed to set up an Association Forum of Indonesian Local Governments. The
Association of Local Governments was merged to form one organization based on particular interests. This is in accordance with Wahab (1990), stating that individuals and group swith similar backgrounds and interests would join together, both formally and informally to impose their interests up on the government. Their behaviours would have more political significance when they act on behalf of a particular group/network.

Parliament consists of the Central Parliament, the Association of Indonesian Municipal Parliament (ADEKSI), the Association of Indonesian District Parliament (ADKASI) and the Regional Advisory Council (DPD). International organizations involved in the process are the Ford Foundation, GTZ, USAID, World Bank and JICA.

\section{Interest}

Policy-making process is influenced by various groups of interests by using power and authority (Sutton, 1999). Each of the involved actors formed coalitions based on their missions and interests, as shown in Table 3.

The Ministry of Home Affairs and the House of Representative played an important role in the process of division of authority among levels of government. Ministry of Home Affairs formulated their vision of the decentralization policy. Parliament represented political parties, especially the major parties. At that time, the implementation of decentralization was considered to be out of control. The House of Representative and The Ministry of Home Affairs formed a coalition to work together to revise

Table 2. Actors involved in policy-making process of division authority

\begin{tabular}{|c|c|c|c|c|c|c|c|}
\hline \multirow[t]{2}{*}{ No } & \multirow[t]{2}{*}{ Actor } & \multicolumn{2}{|c|}{ Popular text } & \multicolumn{2}{|c|}{ Scientific text } & \multicolumn{2}{|c|}{ Total } \\
\hline & & $\begin{array}{l}\text { Frequency } \\
\text { (times) }\end{array}$ & $\begin{array}{c}\text { Percent } \\
(\%)\end{array}$ & $\begin{array}{l}\text { Frequency } \\
\text { (times) }\end{array}$ & $\begin{array}{c}\text { Percent } \\
(\%)\end{array}$ & $\begin{array}{c}\text { Frequency } \\
\text { (times) }\end{array}$ & $\begin{array}{c}\text { Percent } \\
(\%)\end{array}$ \\
\hline 1. & Parliament & 14 & 13.73 & 4 & 3.92 & 18 & 17.65 \\
\hline 2. & $\begin{array}{l}\text { Local Government } \\
\text { Association }\end{array}$ & 15 & 14.71 & 4 & 3.92 & 19 & 18.63 \\
\hline 3. & Central Government & 29 & 28.43 & 6 & 5.89 & 35 & 34.31 \\
\hline 4. & $\begin{array}{l}\text { University/ } \\
\text { researcher/expert }\end{array}$ & 9 & 8.82 & 8 & 7.84 & 17 & 16.67 \\
\hline 5. & Business people & 1 & 0.98 & 1 & 0.98 & 2 & 1.96 \\
\hline 6. & NGOs & 5 & 4.91 & 1 & 0.98 & 6 & 5.88 \\
\hline 7. & $\begin{array}{l}\text { International } \\
\text { Organizations }\end{array}$ & 4 & 3.92 & 1 & 0.98 & 5 & 4.90 \\
\hline & Total & 77 & 75.49 & 25 & 24.51 & 102 & 100 \\
\hline
\end{tabular}

Source : Analysis of primary data (2010) 
previous policies on decentralization. The Ministry of Home Affairs and the House of Representative had a strong position to determine the policy for division of authority among levels of governments. This is in accordance with the opinion of Sutton (1999), who stated that the policy making process is influenced by interest groups by using power and authority.

The Association of Indonesian District Government and the Association of Indonesian Municipal Goverment incorporated in the Association Forum of Indonesian Local Government. They stated that it was common if there were some weaknesses in the implementation of the decentralization because at that time the policy was in the transition phase (1999-2001) and entered into the installation phase (20022003). Consolidation was implemented from 2004 to 2007.

On 27th July 2005, Association of Provincial Government of Indonesia (APPSI) held workshops in 10 provinces to prepare Draft Regulation for division of authority between central and local government levels and to formulate the governor's authority in meeting with the House of Representative. Due to the unclear role of the provincial government under Law No. 22/1999, APPSI was very concerned to revise the law. According to YAPPIKA (2006), private sector was also very concerned with the existence of "legal certainty" in the area. The implementation of regional autonomy resulted in the uncertainty of the legal aspects, because of the uncontrolled Regional Regulations that inhibited the business sector at the local level. The World Bank study on decentralization in Indonesia showed that overlapping rules made delegation of authority blurred. Tax system became chaotic and emerging regulations made investors worried.

USAID through its Local Governance Support Program had activities to strengthen local governance in Indonesia. Ford Foundation supported by several communities were oriented toward reformation of village governance. GTZ played a role in increasing the country's capacity to implement decentralization and good governance. YAPPIKA (2006), stated that the influence of these NGO sto the policy-making process for division of authority among levels of government was not significant. Overview of the three discourses in the division of authority between levels of government is presented in Table 4.

Story line of the democratic discourse is the policy narrative of externality and accountability, supported by Association Forum of Indonesian Local Government and decentralization experts. Story line of the economic discourse is a policy narrative of efficiency supported by business entity, APPSI and the World Bank. Coalitions of democratic and economic discourses use story line of externality, accountability and efficiency, supported by the Ministry of Home Affairs and House of Representative.

Discourse helps certain interest groups to be able to overcome the dominance of other interest groups, by defining issues, providing a framework of thinking, providing argument on selected alternatives, and impact of policy implementation (Sutton, 1999). Ministry of Home Affairs and House of Representative combine both discourses to address the issue of decentralization.

Based on these three criteria, the Minister of Home Affairs issued a circular letter to each sector (eg. forestry, agriculture, mining, environment) to

Table 3. Coalition and interests of actors involved in the policy-making process for division of authority

\begin{tabular}{|c|c|c|c|}
\hline No & Coalition & Actorsinvolved & $\begin{array}{r}\text { Interest } \\
\end{array}$ \\
\hline 1. & Coalition of democracy and economy & $\begin{array}{l}\text { Ministry of Home Affairs and the House } \\
\text { of Representatives }\end{array}$ & $\begin{array}{l}\text { Realizing decentralization that is } \\
\text { democratic and efficient }\end{array}$ \\
\hline 2. & Pro democracy & $\begin{array}{l}\text { ADEKSI, ADKASI, APKASI, } \\
\text { APEKSI, decentralization expert }\end{array}$ & $\begin{array}{l}\text { Maintaining the system of } \\
\text { authority division of open end arrangement } \\
\text { /general competence }\end{array}$ \\
\hline 3 & Pro economy & APPSI, businessman, World Bank & $\begin{array}{l}\text { - Fight for the province's role are } \\
\text { unclear } \\
\text { - business certainty }\end{array}$ \\
\hline
\end{tabular}

Source : Analysis of primary data (2010) 
Table 4. Overview of the three discourses in the policy making process for division of authority among levels of government ${ }^{2}$

\begin{tabular}{|c|c|c|c|}
\hline & Democratic discourse & Economic Discourse & Democratic and economic discourse \\
\hline $\begin{array}{l}\text { Typical } \\
\text { proponents } \\
\text { (organizations } \\
\text { and disciplines) }\end{array}$ & $\begin{array}{l}\text { Association Forum of } \\
\text { Indonesian Local } \\
\text { Government and } \\
\text { decentralization expert }\end{array}$ & $\begin{array}{l}\text { - Proponents } \\
\text { of centralization (businessm } \\
\text { an, entrepreneur) } \\
\text { - APPSI, World Bank }\end{array}$ & $\begin{array}{l}\text { - Ministryof Home Affairs } \\
\text { - House of Representative }\end{array}$ \\
\hline $\begin{array}{l}\text { Central } \\
\text { argumentof story } \\
\text { line }\end{array}$ & $\begin{array}{l}\text { - Externality refers to } \\
\text { impact/consequences that } \\
\text { may appear from the } \\
\text { implementation of } \\
\text { government affairs. } \\
\text { - Accountability based on } \\
\text { proximity to the impact } \\
\text { caused by the delivery of the } \\
\text { affair. }\end{array}$ & $\begin{array}{l}\text { Efficiency: autonomy should } \\
\text { be efficient, should not be } \\
\text { high cost economy. }\end{array}$ & $\begin{array}{l}\text { Finding the win-win } \\
\text { solution. Democratic principle (externality, } \\
\text { accountability) and principle of } \\
\text { economic (efficiency) }\end{array}$ \\
\hline Priorities/mission & $\begin{array}{l}\text { Building } \\
\text { a democracy in governance }\end{array}$ & $\begin{array}{l}\text { Provide public } \\
\text { services effectively, efficiently } \\
\text { and economically }\end{array}$ & $\begin{array}{l}\text { Realizinga } \\
\text { democratic and efficient governance }\end{array}$ \\
\hline $\begin{array}{l}\text { Positioning } \\
\text { of proponents (self } \\
\text { representation) }\end{array}$ & $\begin{array}{l}\text { - Community participationin } \\
\text { governance } \\
\text { - Equity among citizens } \\
\text { - More secure accountability to } \\
\text { the community }\end{array}$ & $\begin{array}{l}\text { Efficiency of affairs is } \\
\text { important in the era } \\
\text { of globalization }\end{array}$ & $\begin{array}{l}\text { Decentralization in Indonesia is different } \\
\text { from decentralization in other countries }\end{array}$ \\
\hline $\begin{array}{l}\text { Positioning of } \\
\text { opponents (other } \\
\text { representation) }\end{array}$ & $\begin{array}{l}\text { Economic principles are } \\
\text { considered undemocratic }\end{array}$ & $\begin{array}{l}\text { Democratic principle is } \\
\text { considered in efficient }\end{array}$ & $\begin{array}{l}\text { - The principle of democratic is } \\
\text { considered inefficient } \\
\text { - The principle of efficiency is } \\
\text { considered undemocratic }\end{array}$ \\
\hline
\end{tabular}

Table adopted from Wittmer and Birner (2003)

Source: Analysis of primary data (2010)

prepare a draft of division of authority. Decision on activities to be decentralized was decided by the respective ministries. Each ministry had a meaning ${ }^{4}$, which criteria should be prioritized. Protected forest management has been decentralized by the Ministry of Forestry to the District Government.

In practice it is very difficult to implement the use of the three criteria. Implementation of externality criteria is not simple because local governments have of ten lack of attention to the impact of their activities to other parties outside their jurisdiction. Criteria of efficiency and its implementation are always directed towards the scale of economy. These are therefore some of the issues that tend to be handed over to the higher government. Criteria of accountability tend to refer to the level of government closer to

\footnotetext{
${ }^{2}$ Table is analyzed from 56 documents, consisting of 33 popular papers (16 papers from printed media and 17 from website) and 23 scientific papers (10 scientific articles, 5 scholarly journal papers and 8 books).

${ }^{3}$ Hajer (1995) in Wittmer and Bitner (2003), defines a story line as generative sort of narrative on social reality through which elements from many different domains are combined and that provide actors with a set of symbolic references that suggest a common understanding

${ }^{4}$ In-depth interview with Senior Adviser to Minister of Governance Sector, Ministry of Home Affairs
}

the community. Division of authority has not considered the local capability, which allows central and local governments to optimally run the authorities. The result of the study also shows that division of authority between centralprovincial-district governments in Indonesia and the strength of uniformity of central policy toward local governments, lead to conflict at local level. The policy did not consider diversity, potency and readiness of the regions ${ }^{5}$.

\section{Policy Space}

The concept of policy space is associated with the degree to which policy makers are limited by forces such as networking of dominant actors or narrative. If there is strong pressure to adopta particular strategy, the decision maker does not have a lot of space to consider more diverse options. Actor or a network that has powerful capacity (leverage) over the process can insist their preferences in the formation of policy options (IDS, 2006). This happens in the policy-making

${ }^{5}$ See Draft Academic Paper of Revision of Law No.32/2004 on Local Government prepared by the Ministry of Home Affairs and GTZ, 2009 
process for division of authority, the Ministry of Home Affairs and the House of Representative have a strong political power to insert their narrative policies in the decision making process.

A criterion of division of authority based on the principle of externality in its implementation has encountered problems, as it requires redefinition of externality. According to the Draft of Local Government Academic Manuscript, prepared by a team of University of Indonesian experts and DRSP, and received inputs from members of DPD-RI in the process of the revision of Law No. 32/2004, the higher government does not have to take care of all aspects with broader impact, but it only needs to set the regulation, in order to protect the interests of the wider society. For example, the rule of disposal can be arranged at province level. If disposal of garbage or waste from a city resulting in pollution of rivers that flow to other districts the affairs of garbage disposal is not the authority of the provincial government. Externality is not just a theoretical issue, but can also be pragmatic, and can be changed dynamically. Rule of affairs division should be dynamic and always be reviewed.

The existing policy narratives in policy-making process for division of authority among levels of government are less dominant; therefore these policy narratives can only be used as a complement, namely as policy narratives of interdependence. This policy narrative becomes important when it is connected with authority which has impact across the region. Implementation of the interdependence narrative among the regions also found many obstacles. District governments tend to think that all affairs that have been authorized are only their affairs and ignore the interdependence among district governments in implementation of their affairs. According to Draft Academic Paper of Revision of Law No. 32/2004on Local Government prepared by the Ministry of Home Affairs and GTZ (2009), interdependence affairs are more likely tobe placed at the provincial government level, because it covers authority of some district governments.

Discourses of externality and interdependency should be more emphasized to change the current policies. In particular, the division of authority of natural resources that is interconnected among regions. For example, the management of protected forest that has impacts in several districts, should be at provincial level. There is an opportunity to consider both two discourses. However there are some problems arising such as the resistance of districts and the in efficiency of forest management. To cope with these problems, it is suggested to apply an asymmetrical decentralization strategy. In this strategy, decentralization of forest management could be adjusted to the characteristics of each region and socio-economic conditions of local communities.

Understanding the policy process through testing of knowledge/narrative, actor/networks and political/interest can help to identify the policy space. The articulation of alternative narratives is possible where there are weaknesses in the articulation of the dominant narratives. This condition requires the identification of space to join the network, or the listed key actors into alternative networks (IDS, 2006). Redefinition of externalities and interdependence criteria can be used as anarrative policy to improve the policy of division of authority among levels of government.

\section{CONCLUSION}

There are three discourses in the policy-making process of decentralization of the management of protected forests, namely :1) democratic discourse (with central argument of externality and accountability, supported by the Association Forum of Indonesian Local Government and experts of decentralization); 2) economic discourse (with central argument of efficiency, supported by business entity, APPSI and the World Bank); and 3) democratic and economic discourse (the coalition of democratic and economic discourse constructed from externality, accountability and efficiency policy narrative, supported by House of Representative and the Ministry of Home Affairs).

To improve the policy on division of authority levels of government, it is suggested : 1) to redefine the criteria of externality and interdependence that can be used as new narrative in formulation of the next policy and 2) to communicate with dominant actors/network 
(Ministry of Home Affairs and the House of Representative) to influence policy change. Redefinition of externality means the higher level of government does not necessary take into account all aspects that have wide impacts, it is enough to regulate them. Communication should be carried out through discussion and dialogue in relation to next policy recommendation.

\section{ACKNOWLEDGEMENTS}

We would like to thank Dr Made Suwandi MSoc (Senior Adviser to Minister of Governance Sector, Ministry of Home Affairs) and Prof. Dr. Eko Prasodjo MSc (Lecturer at Faculty of Social and Political Science, University of Indonesia) who had became key informant in this research. We appreciate Ms. Mega, Mr. Sulistyo and Mr. Ari for English editing.

\section{REFERENCES}

Barr, C., Resosudarmo, I. A., Mc.Carthy, J., \& Dermawan, A. (2006). Forest and Decentralization in Indonesia: and Overview. In C. Barr, I. A. Resosudarmo, A. Dermawan, \& J. McCarthy (Eds.), Decentralization of Forest Administration in ndonesia. Implications for Forest Sustainability, Economic Development and Community Livelihood (pp. 1-17). Bogor: CIFOR.

Eriyanto. (2005). Analisis Wacana: Pengantar Analisis Teks Media. Yogyakarta: LKIS.

Experts, T. o. (2009). Draf Naskah Akademis UndangUndang yang mengganti UU No. 32 Tabun 2004 tentang Pemerintahan Daerah. PAH 1 DPD-RI.

Faircloug, N. (2006). Discourse and Social Change. Cambridge, United Kingdom: Polity Press.

Hoessin, B., \& Prasodjo, E. (2009). Konsep Pembagian Kewenangan (Urusan) antar Tingkat Pemerintahan. Retrieved June 2, 2009 , from http://www.desentralisasi.org

IDS. (2006). Understanding Policy Processes A Review of DS Research on the Environment. Knowledge, Technology and Society Team Institute of Development Studies University of Sussex, Brighton UK.

Kartodihardjo, H. (2006). Ekonomi dan Institusi Pengelolaan Hutan: Telaah Lanjut Analisis Kebijakan Usaha Kehutanan. Bogor: Ideal.
Parsons, W. (2008). Public Policy: Pengantar Teori dan Praktik Analisis Kebijakan. (T. W. Santoso, Trans.) Jakarta: Prenada Media Group.

Ratnawati, T. (2003). Hubungan Kewenangan Antara Pemerintah Pusat dan Daerah dalam Otonomi Daerah di Indonesia: Peluang, Kendala dan Implikasi. Jakarta: Pusat Penelitian Politik LIPI.

Ribot, J. C., \& Larson, A. M. (2005). Democratic Decentralisation through a Natural Resource Lens. London: Taylor \& Francis Group.

Satija. (2003). Mengurai Konflik Desentralisasi di Indonesia: Arogansi Pemerintah Daerah atau Pemerintah Pusat. Jurnal Kebijakan dan Administrasi Publik, 7(2), 53-71.

Sutton, R. (1999). The Policy Process : An Overview (Working Paper 18). London: Overseas Development Institute.

Suwandi , M. (2002). Pokok-Pokok Pikiran Konsepsi Dasar Otonomi daerah Indonesia (Dalam Rangka Mewujudkan Pemerintah Daerah yang Demokratis dan Efisien). Direktorat Jenderal Otonomi Daerah, Departemen Dalam Negeri . Jakarata: Direktorat Fasilitasi Kebijakan dan Pelaporan Otonomi Daerah.

Team of University of Indonesian experts. (2009). Draf Naskah Akademis Undang-Undang yang mengganti UU No. 32 Tahun2004 tentang Pemerintahan Daerah. PAH 1 DPD-RI.

The Ministry of Home Affairs. (2009). Academic Paper Draft of Revision of Law 32/2004 on Local Governmentprepared by the Ministry of Home Affairs and GTZ.

Wahab, S. A. (1990). Pengantar Analisis Kebijaksanaan Negara. Jakarta: Rineka Cipta.

Wittmer, H., \& Birner, R. (2003). Between Conservationism, Eco-Populism and Developmentalism Discourses in Biodiversity Policy in Thailand and Indonesia. Jerman: Institute of Rural Development Georg-August University of Göttingen.

YAPPIKA. (2006). Konteks Historis Perubahan UndangUndang Pemerintah Daerah (UU No22/1999 menjadi UU No.32/2004). Kerjasama Partnership Kemitraan dan Flegt.

Zuhro, S., Sjarmidi, A., Chaniago, A., Wardiat, D., Romli, L., Sukarno, M., et al. (2006). Naskah Akademik Menata Kewenangan Pusat-Daerab yang Aplikatif-Demokratis. Jakarta: LIPI Press. 
